\title{
Teachers' Perceptions of the Standard-based English Language Curriculum in Malaysian Primary Schools
}

\section{Suriati Sulaiman}

Dr., Faculty of Educational Studies, Universiti Putra Malaysia, 43400 Serdang, Selangor, Malaysia, sulaimansuriati@yahoo.com

\section{Tajularipin Sulaiman}

Dr., Sports Academy/ Faculty of Educational Studies, Universiti Putra Malaysia, 43400 Serdang, Selangor, Malaysia, tajulas@upm.edu.my

\section{Suzieleez Syrene Abdul Rahim}

Faculty of Education, University Malaya, 50603 Kuala Lumpur, Malaysia, suzieleez@um.edu.my

Standard-based English language curriculum (SBELC) was fairly a new curriculum in Malaysian primary schools. The implementation of SBELC is a phenomenon affecting all teachers and pupils in primary education. Since curriculum implementation occurs mostly in the classroom and teachers are the key players in the implementation process, the initial concern should be teachers' perceptions towards the new language curriculum. Teachers' perceptions towards the curriculum determine their acceptance and readiness. Therefore, a multiplecase study was carried out that involved five teachers from five national primary schools to investigate teachers' perceptions towards the implementation of the SBELC and data were analysed from classroom observations, semi-structured interviews, and corresponding documents. The findings suggested the participants had positive perceptions towards the new language curriculum which were the early indicator of their acceptance and readiness to implement the standard-based English language curriculum. This paper attempts to discuss teachers' perceptions of the standard-based English language curriculum as progressive, pragmatic and outcome-based curriculum in Malaysian primary schools.

Keywords: curriculum implementation, standard-based curriculum, English language curriculum, progressive curriculum, pragmatic curriculum, outcome-based curriculum

\section{INTRODUCTION}

The implementation of SBELC is a phenomenon affecting all teachers and pupils in Malaysian primary schools. Once a new curriculum is implemented throughout the

Citation: Sulaiman, S., Sulaiman, T. \& Abdul Rahim, S. S. (2017). Teachers' Perceptions of the Standard-based English Language Curriculum in Malaysian Primary Schools. International Journal of Instruction, 10(3), 195-208. https://doi.org/10.12973/iji.2017.10313a 
entire school system, it is expected that its effectiveness will increase as time goes by. In the process, teachers may gain experience and adjust to new curriculum content and teaching methods. However, in some cases, a new curriculum that proven effective in the pilot stage may turn out to be less effective once it is fully implemented throughout the education system (Kim, 1977). After three years being enacted, teachers are expected to properly implement the standards-based English language curriculum. To ensure that the new curriculum contributes to the attainment of the educational goals of the nation, the implemented curriculum entails proper and continuous monitoring by interested parties who need to know where and how to improve the curriculum product (Lewy, 1977), and as such, someone must monitor what is occurring and determine whether these actions are appropriate (Ornstein \& Hunkins, 2014). Though some studies have been done by the Ministry of Education but there is no specific knowledge on the implementation of SBELC in actual classroom setting.

Since curriculum implementation occurs mostly in the classroom and teachers are the key players in the implementation process, the initial concern should be the teachers' reactions towards the new language curriculum. The new curriculum can succeed only if teachers accept it. The acceptance by teachers of an educational programme is a prerequisite for its success. If teachers do not accept the programme, one can hardly expect that it will be properly implemented (Soto, 1977). Furthermore, to determine whether the teachers accept the new curriculum and are ready to implement it, one should gather data on teachers' perceptions (Kim, 1977). Likewise, teachers are more likely to teach English successfully if they have positive outlook of the new language curriculum.

By acknowledging teachers' perceptions of SBELC, the educational leaders may anticipate whether the teachers accept the new English language curriculum and are ready to implement it or not because teachers' perceptions are the early indicators of teachers' acceptance and readiness. However, there is no specific data on Year One teachers' perceptions of the new language curriculum; for which reason this study was proposed.

\section{Objective of the Study}

The study was part of a larger study that aimed to investigate teachers' implementation of the standard-based English language curriculum in Malaysian primary schools. The issue was explored through seven research questions but this paper will only discuss one of the seven research questions which is : what are teachers' perceptions of the standardbased English language curriculum?

\section{METHOD}

\section{Research Design}

The researcher used qualitative case study as the research approach. Case study allows researcher to investigate a phenomenon in-depth over a period of time through a number of cases in actual setting. To get rich information, five Year 1 English teachers who were teaching at five national primary schools of different contexts were chosen. Each 
individual teacher was the subject of an individual case study, but the study as a whole covered five teachers and in this way the study used a multiple-case design. It was called multiple-case study because several cases were studied jointly in order to investigate a phenomenon (Stake, 2005). The five cases were chosen for in such aggregate, the case study might predict contrasting results (a theoretical replication), pursued two different patterns of theoretical replications, provided compelling support for the initial proposition, and attained a high degree of certainty about the multiple-case results (Yin, 2009). In each situation, an individual teacher was the case being studied, and the individual teacher was the primary unit of analysis. Since teachers were the key players in implementing the standard-based English language curriculum in primary schools, so, they were the main unit of analysis, being addressed by the research question.

The implementation process of English language curriculum differs in relation to the facilities of schools and classrooms, teachers' and pupils' characteristics (Yanik, 2007). Respectively, case selection was done after taking into consideration teacher expertise development (Berliner, 2004) and school bands (based on national category) and school clusters (based on participating district category). By looking at the implementation process executed by teachers of different stages of teacher expertise development in schools of different bands and groups, the study allowed the researcher to investigate the central phenomenon at different contexts.

\section{Data Collection}

The qualitative data were collected from one-to-one, semi-structured interviews. By interviewing, the researcher is able to develop insights on the participants understanding of the phenomenon under study (Bogdan \& Biklen, 2011) that the researcher could not find out through observation. The participants were interviewed twice and every conversation was recorded using a mechanical device upon the participants' approval. The use of voice recorder seems prudent to ensure that the researcher does not change what has been said because of misinterpretation either consciously or unconsciously or record words more slowly than they are spoken (Patton, 2002).

Prior to the interviews, the researcher prepared the interview guide, which consists of a list of questions or issues to be explored in the course of the interview, provides a framework within which the interviews develop questions, sequence those questions, and make decisions about which information to pursue in greater depth (Patton, 2002). While preparing the questions, the researcher referred to several studies on curriculum implementation (Barret-Mynes, 2013; Bryan, Ortlieb, \& Cheek, 2013; Hu, 2008; Nguyen, 2013; Yanik, 2007) and a peer debriefer who was an associate professor in the field of study, Curriculum and Instruction to review and ask questions about the study so that the study was examined by people other than the researcher. In this context, the interview guide served as a basic checklist during the interview to ensure that common information is obtained from the participants by covering the same topics and issues. Thus, it kept the interaction focused and ensured the researcher fully used the limited time available in an interview situation. 


\section{Data Analysis}

Since the raw data of interviews were quotations, the verbal data needed to be fully transcribed. Once the transcriptions were ready, the participants were given a copy of the transcripts to check for its content and spelling accuracy. To create transcripts for interview data, the researcher adapted a few guidelines from Creswell (2012). Using a computer, the researcher first wrote detailed header that contained information about the interview, such as number of interview, date, time, place, and interviewee. Then, the researcher created three columns to record the codes, text document, and themes. The researcher transcribed all the interviewees' words as text document. The researcher left extra space on the page between the interviewer's comments and the interviewee's comments so that she could distinguish clearly between speakers during data analysis. Next, the researcher highlighted the questions asked by the interviewer to indicate where one question ended. Later, the researcher wrote down notes in the 2-inch margins on each side of the text document. On the left side, the researcher inserted codes and on the right side, emerging themes. For codes, the researcher used two or three words as labels. The words were actual words used by the participants during the interviews. For themes, the researcher categorized the codes before came up with the themes.

To pursuit a trustworthy study, the researcher adapted several techniques advocated by Lincoln and Guba (1985) namely triangulation, member checking, peer debriefing, thick description, inquiry audit by external auditor, and audit trail.

\section{FINDINGS}

When asked about the standard-based English language curriculum, almost all participants perceived that it is a good curriculum and even better from the former curriculum as it characterizes progressive, pragmatic and outcome-based curriculum. On top of that, they noticed a few significant changes in the new language curriculum, thus made it different from the former curriculum.

\section{Progressive Curriculum}

All participants acknowledged that the new language curriculum focused on studentcentred, while teacher-centred teaching approach was commonly in practice in the former language curriculum. Student-centred teaching approach focuses more on what the pupils do in order to learn than what the teacher does. Therefore, as an important part of the teaching and learning approach, the new language curriculum emphasizes active learning approach to engage pupils in their learning. Respectively, teachers are expected to design teaching strategies, activities, and instructional materials that meet the differing needs and abilities of pupils to give them a chance to actively engage with the content. In relation to student-centred teaching approach, RP3 described the role of a teacher in the new language curriculum as a facilitator who guides the pupils to discover knowledge and skills themselves through various learning opportunities.

KSSR English is more student-centred rather than teacher oriented. In KSSR English, the method of teaching and learning is student-centred while in KBSR English, it is more on teacher-centred. In KSSR English, teacher is only the facilitator. A teacher 
guides the pupils to discover things by themselves through discussions, group works, presentations and other engaging activities.

(RP3: Interview 1/Q3)

Since pupils are responsible on their own learning, RP3 stated that pupils will be more appreciative of their own efforts which resulting in memorizing things that they have worked on better. Hence, she thought student-centred was a good approach.

In KBSR English, teacher feeds the pupils with everything. The pupils are not actively involved in finding and collecting information or problem-solving. In KSSR English, pupils become more appreciative of their own efforts and will memorize things that they have worked on better. It is a good approach.

(RP3: Interview 1/Q3)

In response to student-centred teaching approach, RP2 acclaimed that the new curriculum encouraged the pupils to actively participate and talk more in the classroom. She believed that this practice was good because pupils became more active in the classroom. The pupils could take part in the discussion where they could give their opinions and share their ideas to the class. Through such communicative activities, RP2 anticipated the pupils could develop self-confidence in communication.

The latest curriculum is student-centred. The focus shifts to the pupils. Teach pupils how to think, solve problems, cooperation and give them more control in the classroom. Teacher acts as a guide. Pupils become more active in class. It encourages pupils to participate in the class where the pupils can give their opinions. The pupils are more active in the classroom. More to group work which they need to discuss questions in the textbook or worksheet and later, present their ideas to class. Pupils could develop selfconfidence in communication through communicative activities.

(RP2: Interview 1/Q3)

Using student-centred teaching approach, the participants focused on pupils and involve them actively in the teaching and learning activities. In doing so, the participants planned varied communicative activities tailored to pupil's abilities and needs. Pupils are guided to enforce understanding according to their respective pace of learning due to individual differences and differing abilities. In brief, the new curriculum expects the teachers to give due emphasis on student-centred approach in teaching and learning strategies as well as activities. In response to student-centred teaching approach, pupils are expected to take an active role in the teaching and learning process. What has been discussed earlier about teachers' and pupils' roles shows that the new language curriculum features a progressive curriculum which always gives emphasis on studentcentred.

Given the aim of the new language curriculum is to enable the pupils to communicate effectively in a variety of contexts that is appropriate to their level of development, teachers are, therefore, recommended to use communicative approach or communicative language teaching (CLT) that emphasizes communication as both the mean and the 
ultimate goal of language learning. The language learning takes place mostly through student-to-student, student-to-teacher, and teacher-to-student interaction especially during the implementation of CLT-based activities. Through CLT, pupils are expected to be able to communicate with their peers and adults confidently and appropriately in formal and informal situations. However, CLT is not the default approach for developing communicative abilities. The approach to teaching English in Malaysian schools is eclectic in which teachers may employ any method that gives due importance to both language learning and acquisition.

\section{Pragmatic Curriculum}

Four out of five participants regarded the new language curriculum as a good curriculum, while three of them thought that it was even better than the former curriculum because the curriculum helps the pupils a lot in mastering the English language. One of the participants, RP5 claimed the recent language curriculum was able to help the pupils become more proficient in English in future due to the fact that the language teaching and learning was more focused as teachers know what to teach and pupils know what to learn. It gave them clear picture of what they need to achieve (learning outcomes) at the end of the lesson. Thus, in the new curriculum, teachers and pupils should know what and how to master English which is essential for pupils in order to gain access to information and knowledge written in English.

I think it is very good because it helps the pupils a lot in mastering the English language. It emphasizes the language skills: reading, writing, listening, speaking, grammar, and language arts. It is more focused. Teacher knows what to teach and pupils know what to learn. Teacher can teach using the focused skills given per day. It gives the teacher clear picture of what they need to achieve (learning outcomes) at the end of the lesson.

\section{(RP5: Interview 1/Q3)}

One participant, RP3 asserted the standard-based English language curriculum integrated many language skills for pupils to learn during English lesson, such as dictionary skills, scanning, scheming, and penmanship which is good for pupils because they will learn English faster and easier. She explained some of the skills were also taught in the former curriculum, however, pupils learned the skills indirectly. Conversely, the SBELC develops language skills systematically during early years of schooling, and thus, pupils' progress in corresponding language skill can be monitored and problems in relation to language learning of each skill could be addressed efficiently.

KSSR English is better than KBSR English because KSSR English integrates many skills for pupils to learn, such as dictionary skills, reading skills as in scanning, scheming, and penmanship. This is good because they will learn English faster and easier. They did learn such skills in previous curriculum, but indirectly. KSSR English develops the language skills systematically during early years of schooling, and thus, progress can be monitored and problems could be encountered efficiently. 


\section{(RP3: Interview 1/Q3)}

The integration of various language skills in the new curriculum is to help the pupils build a strong foundation of salient language skills and sub-skills as defined in the learning standards. Basic listening and speaking skills will help the pupils enrich their understanding of the language. The phonics skill will help the pupils begin to read and a good foundation in penmanship will help the pupils acquire good handwriting. The integration of language arts in the lesson will motivate the pupils to learn the language in a fun way and thus enjoy language learning.

One of five participants even perceived that the recent curriculum gave more emphasis on language practice for pupils to build strong foundation in English. According to RP4, pupils had more time to practise the language during English lessons.

I think it is a good curriculum. The standard-based English language curriculum is even better than the previous one. The new curriculum helps pupils learn English better and acquire strong foundation in the language. Teacher can build strong foundation of the English language skills to pupils because pupils have more time to practice the language skills they have learned.

(RP4: Interview 1/Q3)

In line with the government's policy on strengthening English, the new curriculum has been designed to produce pupils who will be more proficient in the language. The goal of the English language curriculum is then to help pupils acquire the language in order to help them use it in their daily lives, to further their studies, and for work purposes. To help pupils acquire the language, RP4 concluded teachers need to provide more opportunities for pupils to practice the language skills that they have learned in the classroom through engaging activities. The practice aims to give pupils intensive practice in the target language, as well as to build up pupils' confidence in their ability to use the target language to a level that allows them to participate in the freer communicative situation they will meet in the final phase of the lesson. To ensure that the practice achieves the learning objectives, the pupils need ample practice time. Respectively, the new language curriculum allocates 300 minutes per week for language learning and practice in national primary schools.

The new language curriculum was designed to help pupils acquire the language for daily use, to further study, and for work purposes. It was therefore regarded by RP3 as more convenient to pupils compared to KBSR English because pupils learned English not just for examination. In fact, she confided that pupils learn English so that they are able to converse in simple daily conversation and understand common English language around them.

KSSR English is more convenient to pupils compared to KBSR English because in KSSR English, pupils learn English for daily use, not just for examination. Pupils could learn in a more interesting manner and teachers could improvise their skills. By right, 
pupils should be able to converse in simple daily conversation and understand common English language around them.

(RP3: Interview 1/Q3)

Apparently, the main purpose of language learning in the new language curriculum is not merely getting good grades during the examination. Yet, pupils learn English language for their own convenience. In fact, the English language curriculum provides learning opportunities for the pupils to be able to communicate effectively in a variety of contexts that is appropriate to the pupils' level of development. On top of that, almost all participants were in favour of the new language curriculum for it was non-examoriented which was distinct from the former language curriculum.

Referring to the statements above, it is evident that the new language curriculum focuses on pupils' overall performance in language learning. Therefore, equal attention is given pupils' holistic ability, development, and achievement. Conversely, in exam-oriented curriculum, good grades are all that matters. Teachers and pupils have to invest a lot of their time to ensure that pupils excel in studies. Pupils are forced to know and learn in order to get good grades during examination. This can be easy for some pupils but it can be very difficult for others. Inability to perform only results in stress not only to pupils but also to teachers because the pupils fail to achieve the aim set by the teachers to get higher grades in examination.

Though exam-oriented curriculum has a noble aim, the implementation tends to affect the pupils. Those who have good grades usually get affection while those who have low grades are seen as unworthy to fit into the society and results in low-self-esteem among them. On the other hand, the standard-based English language curriculum regards pupils as unique individuals with multiple intelligences, in which some may excel academically while others possess hands-on expertise. Considering their individual differences, the pupils are given more space to learn the language in a fun way through various engaging activities for the sake of language learning and not aiming for high grades solely.

RP2 even expressed her concern about the outcomes of the previous language curriculum which was exam-oriented. She believed an exam-oriented curriculum produced dependent learners for everything including the answers was given by the teachers. This is due to the fact that most pupils learn the language with the main intention to get good grades during examination. Fear of making mistakes and getting low grades during examination leads them to rely on teachers to provide correct information and answers during language learning and practice.

The previous curriculum was exam-oriented. Answers were provided by the teachers. Everything was spoon feeding. However, the latest curriculum is student-centred. It encourages pupils to participate in the class where the pupils can give their opinions.

(RP2: Interview 1/Q3)

In exam-oriented curriculum, pupils believe that the information should be transmitted from the teachers, they are not used to discovery learning. Therefore, they prefer to 
imitate the teachers in order to avoid doing mistakes rather than make own efforts to search for the answers and information or learn from the mistakes. They learn better by imitating the teachers. Hence, such language curriculum and teacher-centred approach encourage the pupils to be dependent learners. On the other hand, RP5 said that the new language curriculum teaches pupils to be independent learners, in which pupils are responsible on their own learning.

Pupils need to think a lot by themselves. Furthermore, the new curriculum assesses pupils' holistic learning progress and achievement and teaches pupils to be independent learners who could think critically and creatively.

(RP5: Interview 1/Q3)

Based on the above discussion, it is evident that the new language curriculum recommended integration of language skills, more language practice, and non-examoriented approach. The findings explain the ultimate goal of the language curriculum is to prepare the pupils to learn English so that they can use it in their future. Considering the whole emphasis of method of teaching is on pupils and what is useful to the present needs of the pupils, the principle of learning is by doing, and the teacher's role is that of a facilitator and a guide, the new language curriculum is pragmatic in nature.

\section{Outcome-Based Curriculum}

All participants were well-aware that the former language curriculum for Year One was transformed to modular structure, and thus the language curriculum was organized in four modules, namely listening and speaking, reading, writing, and language arts and as recommended by the Curriculum Standard Document, they are to teach according to the given modules.

For Year One and Two, four modules are introduced. They are listening and speaking, reading, writing, and language arts. While grammar is being taught during Year Three to Six.

\section{(RP2: Interview 1/Q3)}

We have to use the given modules. The modules have been given by the Ministry of Education as the guidance to all teachers. It is good to have the modules. Teachers will have more appropriate guidance on what and how to teach the pupils. I like using it. It is already completed and covers everything that needs to be taught to the pupils.

(RP5: Interview 1/Q3)

Each module was designed to be a self-contained and independent unit of learning which focuses on a few well-defined objectives as stipulated in the Curriculum Standard Document. The objectives of language teaching and learning are reflected in the content and learning standards. Teachers then focus on helping the pupils learn what the standards specify and what the pupils need to know and be able to do. This defines the new language curriculum as outcome-based for which the teaching focuses on what the pupils should know and actually do after they are taught in the classroom. 
The organization of the new curriculum in a modular structure received positive feedback from two participants. RP4 and RP5 admitted that the new curriculum which emphasizes on the development of specific language skills through four modules helps pupils learn English better and acquire strong foundation to build their proficiency in the language.

The lessons are divided into modules: listening and speaking, reading, writing, and language arts that help the pupils learn English better and acquire strong foundation to build their proficiency in the language.

(RP4: Interview 1/Q3)

I think it is very effective and helpful in developing pupils' proficiency in English.

(RP5: Interview 1/Q3)

A modular curriculum stresses on clear behavioural outcomes and teaching which progresses in small steps, and encourages active involvement by pupils, immediate feedback through classroom assessment, reinforcement, and self-pacing. Such curriculum allows the pupils to study a module intensively and complete it in a year.

Respectively, the new language curriculum helps the pupils become more proficient in the language through the development of specific language skills under each module. Furthermore, the standard-based English language curriculum focuses on the learning outcomes or the expected performance of what the pupils should know, understand and be able to perform within the respective year. As the teaching and learning process going on, the pupils' learning progress and performance of specific skill are measured against the learning standards as specified in respective modules. Hence, the new curriculum characterizes an outcome-based curriculum.

\section{CONCLUSION}

The participants perceived the standard-based English language curriculum as a curriculum that emphasises student-centred approach. This form of approach encourages active participation among students as well as accommodates different language abilities. Hence, the teacher's role changes to being a facilitator.

Participants expressed that the new language curriculum provided clearer learning outcomes. These learning outcomes reflected more integration of various language skills and elements of the use of the English language in everyday life. The participants view this change as a good way of mastering the English language among students. This in turn, will provide students with a stronger foundation of the language.

Apart from this, the participants were of the opinion that the standard-based English language curriculum also put emphasis on a non-exam-oriented approach. This form of approach allows teachers to obtain a more holistic understanding of students' learning progress. This new curriculum is modular in nature and outcome-based. Students are able to master the language in a paced manner. 
The participants' perceptions about the standard-based English language curriculum as progressive, pragmatic and outcome-based curriculum suggested that all participants had positive outlook of the new language curriculum. According to Ornstein \& Hunkins (2014), teachers' perceptions determine their acceptance of an educational programme and readiness to implement it. Therefore, the participants' positive perceptions towards the new language curriculum are the early indicator of their acceptance and readiness to implement the standard-based English language curriculum.

\section{REFERENCES}

Berliner, D. C. (1994). Expertise: The wonders of exemplary performance. In J. N. Mangieri \& C. C. Block (Eds.), Creating powerful thinking in teachers and students. New York: Holt, Rinehart \& Winston.

Berliner, D. C. (2004). Describing the behavior and documenting the accomplishments of experts teachers. Bulletin of Science, Technology \& Society, 24, 200-212.

Bogdan, R. C., \& Biklen, S. K. (2011). Qualitative Research For Education: An Introduction to Theories and Methods (5th ed.). New Jersey: Prentice Hall.

Creswell, J. W. (2012). Educational Research: Planning, Conducting, and Evaluating Quantitative and Qualitative Research (4th ed.). Boston, MA: Pearson Education.

Creswell, J. W. (2013). Qualitative Inquiry and Research Design: Choosing Among Five Approaches (3rd ed.). Thousand Oaks, CA: Sage Publications.

Creswell, J. W. (2014). Research Design: Qualitative, Quantitative and Mixed Methods Approaches (4th ed.). Thousand Oaks, CA: Sage Publications.

Kim, H. (1977). Quality control of implemented curriculum over time. In A. Lewy (Ed.), Handbook of Curriculum Evaluation (pp. 150-163). Paris: UNESCO.

Lewy, A. (1977). The nature of curriculum evaluation. In A. Lewy (Ed.), Handbook of Curriculum Evaluation (pp. 3-33). Paris: UNESCO.

Ornstein, A. C., \& Hunkins, F. P. (2014). Curriculum Foundations, Principles and Issues (6th ed.). Essex: Pearson Education.

Patton, M. Q. (2002). Qualitative research and evaluation methods (3rd ed.). Thousand Oaks, CA: Sage Publications.

Soto, M. L. (1977). Teachers, parents and community as data sources. In A. Lewy (Ed.). Handbook of Curriculum Evaluation (pp. 247-257). Paris: UNESCO.

Stake, R. E. (2005). Qualitative case study. In N. K. Denzin, \& Y. S. Lincoln (Eds.), The Sage Handbook of Qualitative Research (3rd ed., pp. 443-466). Thousand Oaks, CA: Sage Publications.

Sulaiman, T., Ayub, A.F.M. \& Sulaiman, S. (2015). curriculum change in English language curriculum advocates higher order thinking skills and standards-based 
assessments in Malaysian primary schools. Mediterranean Journal of Social Science, 6(2). 494-500.

Yanik, A. E. (2007). A study of English language curriculum implementation in 6th, 7th and 8th grades of public primary schools through teachers' and students' perceptions (Doctoral dissertation). Middle East Technical University, Turkey.

Yin, R. K. (2009). Case Study Research: Design and Methods (4th ed.). Thousand Oaks, CA: Sage Publications.

\section{Turkish Abstract \\ Malezya İlköğretim Okullarında Standartlara Dayalı İngilizce Dil Programına Yönelik Öğretmen Algıları}

Standart temelli İngilizce dil programı (SBELC), Malezya ilkokullarında yeni bir müfredat olarak geliştirilmiştir. SBELC'nin uygulanması ilköğretimdeki tüm öğretmenleri ve öğrencileri etkileyen bir olaydır. Müfredatın uygulanması çoğunlukla sınıfta gerçekleştiğinden ve öğretmenler uygulama sürecinde kilit rol aynadıklarından, dikkat edilmesi gereken öncelikli konu öğretmenlerin yeni dil programına yönelik algıları olmalıdır. Öğretmenlerin programa yönelik algıları, onların programı kabullenme ve programa hazır olma durumlarını belirler. Bu nedenle, öğretmenlerin SBELC'nin uygulanmasına yönelik algılarını araştırmak için beş ulusal ilköğretim okulundan beş öğretmenin yer aldığ 1 çoklu durum çalışmasıyla yürütülmüşs ve veriler sınıf gözlemleri, yarı yapılandırılmış görüşmeler ve ilgili dokümanlardan analiz edilmiş̧tir.

Anahtar Kelimeler: program uygulamaları, standarda dayalı İngilizce Dil Programı, İngilizce Dil Program1, ilerici program, pragmatik program

\section{French Abstract \\ La perception de professeurs du programme d'études standart-basé de langue anglaise dans écoles primaires malaises}

Le programme d'études à base de norme de langue anglaise (SBELC) était assez(impartialement) un nouveau programme d'études dans des écoles primaires malaises. La mise en œuvre de SBELC est un phénomène affectant tous les professeurs et des élèves dans l'enseignement primaire. Puisque la mise en œuvre de programme d'études arrive surtout dans la salle de classe et les professeurs sont les acteurs clés dans le processus de mise en œuvre, la preoccupation initiale devrait être les perceptions des professeurs vers le nouveau programme d'études de langue. Les perceptions des Professeurs vers le programme d'études déterminent leur acceptation et empressement. Donc, une étude de cas multiple a été effectuée qui a impliqué cinq professeurs de cinq écoles primaires nationales pour examiner les perceptions des professeurs vers la mise en oeuvre du SBELC et les données ont été analysées d'observations de salle de classe, semistructuré des entretiens et des documents correspondants.

Mots Clés: mise en oeuvre de programme d'études, programme d'études à base de norme de langue anglaise, programme d'études de langue anglaise, programme d'études progressif, programme d'études pragmatique 


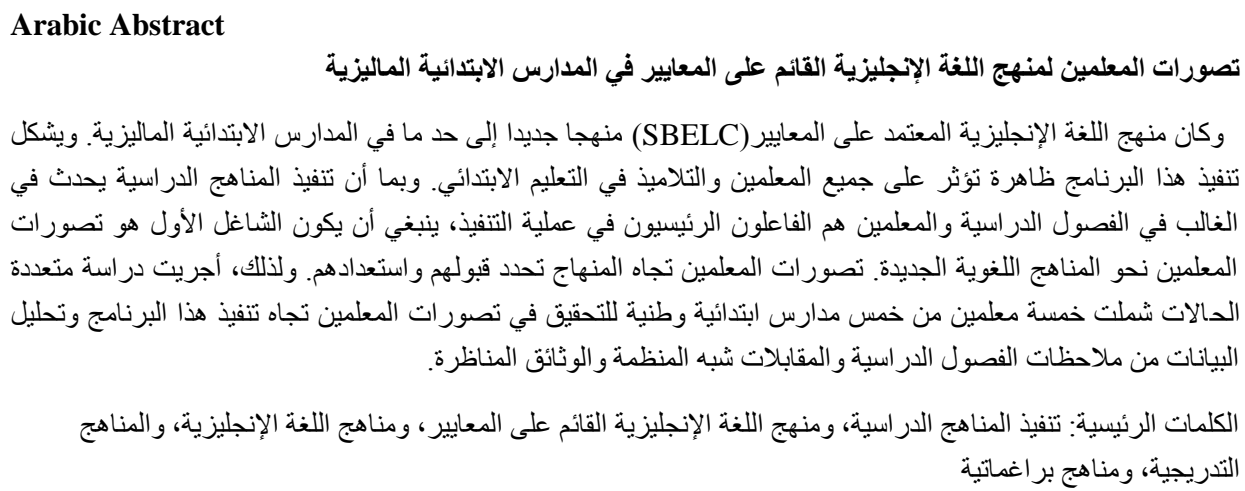

\section{German Abstract}

Lehrer-Wahrnehmung des standardbasierten englischsprachigen Curriculums in malaysischen Grundschulen

Standard-basierte englischsprachige Lehrpläne (SBESL) war ein neues Curriculum in malaysischen Grundschulen. Die Umsetzung von SBESL ist ein Phänomen, das alle Lehrer und Schüler in der Grundschule betrifft. Da die Curriculum-Implementierung vor allem im Klassenzimmer stattfindet und die Lehrer die Schlüsselakteure im Umsetzungsprozess sind, sollte das erste Anliegen die Wahrnehmung der Lehrer gegenüber dem neuen Sprachcurriculum sein. Die Wahrnehmung der Lehrer zum Curriculum bestimmt ihre Akzeptanz und ihre Bereitschaft. Daher wurde eine mehrstufige Studie durchgeführt, an der fünf Lehrer aus fünf nationalen Grundschulen teilnahmen, um die Wahrnehmung der Lehrer zur Umsetzung der SBESL zu untersuchen und Daten aus Klassenzimmerbeobachtungen, halbstrukturierten Interviews und entsprechenden Dokumenten zu analysieren.

Schlüsselwörter: curriculum-implementierung, standardbasierte englischsprachige lehrpläne, englischsprachiges curriculum, progressives curriculum, pragmatisches curriculum 


\section{Malaysian Abstract \\ Persepsi Guru terhadap Kurikulum Bahasa Inggeris yang berasaskan Standard di}

Standard Kurikulum Bahasa Inggeris (SBELC) adalah kurikulum baru di sekolah-sekolah rendah di Malaysia. Pelaksanaan SBELC adalah satu fenomena yang melibatkan semua guru dan murid dalam pendidikan sekolah rendah. Sejak pelaksanaan kurikulum biasanya berlaku di dalam bilik darjah dan guru-guru adalah pemain utama dalam proses pelaksanaan, kebimbangan awal yang perlu diberi persepsi guru terhadap kurikulum bahasa yang baru. Persepsi guru terhadap kurikulum menentukan penerimaan dan kesediaan mereka. Oleh itu, satu kajian pelbagai kes telah dijalankan yang melibatkan lima orang guru dari lima buah sekolah rendah kebangsaan untuk menyiasat persepsi guru terhadap pelaksanaan SBELC dan data dianalisis dari pemerhatian dalam bilik darjah, temu bual separa berstruktur dan dokumen berkaitan.

Kata Kunci: pelaksanaan kurikulum, kurikulum bahasa Inggeris berasaskan standard, kurikulum bahasa Inggeris, kurikulum progresif, kurikulum pragmatik

\section{Russian Abstract \\ Восприятие Учителями Стандартной Учебной Программы по Английскому Языку в Начальных Школах Малайзии}

Основанная на ст6андартах учебная программа по английскому языку (SBELC) была довольно новой учебной программой в начальных школах Малайзии. Внедрение SBELC это явление, затрагивающее всех учителей и учащихся начального образования. Поскольку реализация учебной программы происходит в основном в классе, а преподаватели являются ключевыми игроками в процессе реализации, первоочередной задачей должно быть восприятие учителями в направлении нового языкового учебного плана. Восприятие учителями учебной программы определяет их принятие и готовность. Таким образом, было проведено многоцелевое исследование, в котором участвовали пять учителей из пяти национальных начальных школ, чтобы исследовать восприятие учителями внедрения SBELC.

Ключевые Слова: реализация учебных программ, основанный на стандартах учебная программа по английскому языку, учебная программа по английскому языку, прогрессивная учебная программа, прагматическая учебная программа 